ISSN 2518-1521 (Online), ISSN 2226-2830 (Print)

ВІСНИК МАРІУПОЛЬСЬКОГО ДЕРЖАВНОГО УНІВЕРСИТЕТУ

СЕРІЯ: ІСТОРІЯ. ПОЛІТОЛОГІЯ, 2019, ВИП. 26

\title{
A. Ganchev \\ SPECIAL FEATURES OF BULGARIAN FAMILY INSTITUTION AND ITS TRANSFORMATION IN THE SOUTHERN BESSARABIA IN THE SECOND HALF OF XX CENTURY
}

This paper investigates the changes that occurred in the Bulgarian family of Southern Bessarabia in connection with the destruction of the patriarchal and the emergence of the socialist system. With the inclusion of the Bulgarian community in the Soviet industrial information society, the involvement of state institutions in the upbringing of children, there was a change in the direction of the information broadcast from a vertical intergenerational to the horizontal one within one generation. This led to the irrelevance and loss of traditional knowledge of the group, the keeper of that has always been the third generation, and thus its significance. In this connection, during this period, there is a large percentage of twogenerations families with the new functional responsibilities in comparison with large patriarchal families. There are changes in the appearance of the ethnic Bulgarian village.

Building a new socialist economy, the development of light industry in particular, led to a change in the women's distribution of labor time. In such situation half of the household responsibilities transferred to her husband. There is a dependence on the distribution of labor in the family, depending on the educational level of the husband and wife. All of these factors contributed to the emergence of a new type of socialist family of Bulgarians in the region.

Keywords: family, family relationships, social roles, intergenerational transmission, endo / exogamy, Bulgarians, Southern Bessarabia.

УДК 94(477)"1648/1657"

\section{С. П. Лясковська}

А. А. Лясковська

\section{ЗАСТОСУВАННЯ КОЗАЦЬКИМИ ВАТАЖКАМИ ІНФОРМАЦІЙНО- ПСИХОЛОГІЧНОГО ВПЛИВУ ПІД ЧАС НАЦІОНАЛЬНО-ВИЗВОЛЬНОЇ ВІЙНИ УКРАЇНСЬКОГО НАРОДУ СЕРЕДИНИ ХУІІ СТ.}

У статті на підставі відомих в украӥнській історіографії фактів та раніше опублікованих документальних матеріалів виявлені інформаційно-психологічні впливи, котрі використовували ватажки козацько-повстанського війська у ході Національновизвольної війни 1648-1657 рр. Визначенні об'єкти впливу; проаналізовані технологї (з урахуванням психологї народу) інформаційно-психологічного впливу на широкі верстви, передусім, украӥнського та польського населення, з метою створення сприятливого для повсталих інформаційного простору; особливості застосування методів психологічного тиску на противника та його союзників (переконання, дезінформування, психологічна диверсія тощьо) з метою дестабілізації ситуащії в тилу (провокування соціальних виступів проти польського режиму, організація повстань) та дезорганізації ворожої армії; визначені форми та канали, через які здійснювалися впливи, а також лексичні засоби.

ключові слова: Б. Хмельницький, козацтво, Національно-визвольна війна, інформачійно-психологічний вплив, дезінформування, дезорганізація, психологічна диверсія. 
DOI 10.34079/2226-2830-2019-9-26-27-38

Людство 3 давніх часів використовувало різні форми й методи інформаційнопсихологічного впливу на суспільство. Особливо актуальними вони ставали напередодні та під час воєнних дій, коли між ворогуючими сторонами відбувалося активне інформаційне протиборство. Проблема використання інформаційно-психологічного впливу на суспільство, а також протидії інформаційно-психологічним операціям противника, настільки складна й багатогранна, що й донині залишається недостатньо розробленою.

Сьогодні, в епоху інформаційного суспільства, коли не лише засоби масової інформації (газети і журнали, радіо і телебачення), а й соціальні мережі й інтернет-сайти збирають навколо себе величезну аудиторію користувачів, надзвичайно важливим стає аналіз інформації, яку вони поширюють у суспільстві. А нинішня складна ситуація в Україні, спричинена військовою агресією на сході держави, змушує по-новому оцінювати проблеми безпеки в інформаційній сфері. Очевидними стають питання інформаційних впливів. У цьому контексті здається важливим вивчення історичного досвіду використання інформаційно-психологічних акцій, зокрема, козацьких ватажків під час Національно-визвольної війни українського народу середини XVII ст.

Наукові розвідки, передусім українських дослідників, присвячені тим подіям, уводять до наукового обігу нові факти та важливі документи. Між тим питання використання козацькими ватажками методів інформаційно-психологічного впливу розглядалися як в контексті загального вивчення історії України періоду Національновизвольної війни $[4,13]$, так i, здебільшого, розвитку козацької розвідки та контррозвідки дослідниками Ю. Джеджулою [6], Ю. Мициком [10], В. Степанковим [12, 14], О. Уривалкіним [16] тощо. Особливостям психологічного протистояння між козацтвом та їх противниками присвячені статті О. Куцької [9] та Т. Чухліба [19]. Проте в них наголос робиться, передусім, на дезінформування противника (введення в оману).

Відтак у статті розкриваються сутність і методи інформаційно-психологічного впливу, що застосовувалися козацькою старшиною для консолідації повстанського війська 3 широкими народними масами, а також методики, спрямовані на польське населення, проти війська Речі Посполитої та її союзників.

У XVII ст. гетьмани, отамани та очільники козацьких повстань, не маючи в арсеналі таких понять, як «інформаційно-психологічна війна», «інформаційна операція», активно використовували методи маніпулювання суспільною свідомістю з метою корегування світогляду та поведінки певних осіб та соціальних груп. А гетьмана Богдана Хмельницького сучасні науковці вважають «батьком психологічних війн» [18].

При цьому козацькі ватажки переслідували щонайменше дві цілі: згуртувати навколо себе народні маси та підняти бойовий дух козацького війська; а також нейтралізувати та дезорганізувати вороже військо, а й у міру сил - схилити на свій бік противника, з метою реалізації поставлених завдань.

Відтак, об’єктами спрямування інформаційно-психологічних акцій ватажків козацького війська і зокрема Б. Хмельницького були: безпосередньо козаки та всі ті, хто приєднався до повстанського війська; українське населення; реєстрові козаки, які перебували на службі польського короля; вояки польського коронного війська (жовніри) та 
ISSN 2518-1521 (Online), ISSN 2226-2830 (Print) ВІСНИК МАРІУПОЛЬСЬКОГО ДЕРЖАВНОГО УНІВЕРСИТЕТУ СЕРІЯ: ІСТОРІЯ. ПОЛІТОЛОГІЯ, 2019, ВИП. 26

посполитого рушення (ополчення); польське населення, котре проживало на українських землях - театрі воєнних дій; король і воєначальники польського війська та їх союзники.

Для того, щоб інформація, яка поширювалася серед певних соціальних i національних верств, досягала поставленої мети, гетьману необхідно було враховувати особливі національні, соціальні та етнолінгвістичні характеристики об'єктів впливу; добре розумітися на психології та зважати на інтелект тих людей, на які спрямовувався психологічний вплив. Важливо було знайти й правильну емоційну форму подання інформації.

Зокрема, з метою здобути найширшу підтримку з боку українського населення, створити інформаційний простір, сприятливий для повстанського війська, Б. Хмельницький напередодні та безпосередньо під час воєнних дій неодноразово звертався до народу з універсалами (вчені стверджують, що деякі універсали від імені гетьмана складали й інші козацькі ватажки, хоча їх і підписував Б. Хмельницький). Таку тактику гетьман запозичив у запорожців, які надзвичайно багато уваги приділяли формуванню громадської думки щодо їх іміджу як захисників українського народу.

Пояснюючи мету повстання, Б. Хмельницький наголошував на стражданнях українців, підкреслював, що його місія полягає в тому, щоб захистити свій народ. «Ридання всієї України пробиває небо, прохаючи помсти від Господа Бога, - ось чому я хочу шаблею знищити цього неприятеля», - писав він в одному з універсалів на початку 1648 p. $[5$, c. 626$]$.

У XVII ст., коли православне населення зазнавало всіляких утисків на релігійному грунті, коли Україною ширилося уніатство й відбувалися спроби окатоличення, а православне духовенство зазнавало дискримінації, захист православної віри набував першочергового значення. У чисельних універсалах, з якими Б. Хмельницький звертався до населення для роз'яснення мети виступу та закликами його підтримати, він робив ставку саме на його релігійності, вірності «батьківській вірі». Гетьман, усіляко намагаючись представити себе захисником православ'я, активно використовував такі лексичні звороти, як «мила благочестива віра, яку поляки переводять на унію» [2, с. 80], «батьківська православна греко-руська душеспасенная віра», яку намагалися «звабили та підкорили гвалтом та багатьма нехристиянськими муками й тиранством до згубної унії та римського блуду» [2, с. 79] тощо. Для кращого розуміння простим людом ситуації, що склалася в Україні, в універсалах проводилися аналогії з Біблійними сюжетами. Зокрема, «зрадницька» політика поляків до українців, їх «природних братів», порівнювалася з діями Каїна (уособлення Польщі) по відношенню до його єдинокровного брата Авеля (України). I кульмінацією заклику, свідченням того, що місія гетьмана є праведною, овіяною Божим благословенням, стали слова: «... Допоможе нам всемогутня божа благодать» [2, с. 81].

Проте й пізніше, коли Національно-визвольна війна охопила всю Україну, гетьман наголошував на тому, що захист православної віри є його першочерговим завданням. «Мила нам наша батьківська земля, - писав він у листі до волинської шляхти восени 1650 р., - але природжена віра мусить бути миліша, за неї ми завжди умирали охоче» [7, c. 196].

Будь-який народ з особливою теплотою зберігає пам'ять про пращурів. Їхні подвиги передаються від покоління до покоління, від батьків до синів та онуків. Вихований на народних традиціях, Б. Хмельницький у зверненнях до народу часто згадував «старовічних борців славних», «давніх предків», «старобутніх русів», які були «мужніми й безбоязними», страшними «для навколішніх сусідів». Для них справою «шляхетної честі» 
ISSN 2518-1521 (Online), ISSN 2226-2830 (Print)

ВІСНИК МАРІУПОЛЬСЬКОГО ДЕРЖАВНОГО УНІВЕРСИТЕТУ

СЕРІЯ: ІСТОРІЯ. ПОЛІТОЛОГІЯ, 2019, ВИП. 26

було захистити «цілісність ... вітчизни» [2, с. 79, 80]. Таким чином гетьман, підкреслюючи звитягу предків і вірність їхнім традиціям, підштовхував населення до активних дій проти поневолювачів.

Для посилення емоційного впливу на населення в універсалах використовувалися різноманітні стилістичні мовні засоби, такі як: синоніми, порівняння, метафори, гіперболи, так звані «ідеальні поняття» (свобода, віра, вітчизна, слава, шляхетна чесність) тощо. Зокрема, він називав поляків «наші руйнівники, озлобителі, супостати», які «зневажають, знищують, вельми обсміюють і топчуть» на «наших землях [...] ім'я наше славне козацьке», «запрягли всіх братів наших [...] у невільниче ярмо», «приневолили силою, звабили й підкорили гвалтом» [2, с. 78, 80, 81].

Виступаючи 3 козацьким військом на захист України проти Речі Посполитої та розраховуючи на підтримку 3 боку народних мас, передусім, селянства, гетьману необхідно було враховувати й такий аспект, як ставлення населення до понять «вірності» та «зради». Саме тому Б. Хмельницький намагався довести легітимність повстання. Він усвідомлював, що в очах народу король уособлював не лише владу, а й виступав гарантом спокою, порядку й захисником певних прав і свобод від посягань з боку магнатів і шляхти. Відтак в українському суспільстві в системі громадянських цінностей, на думку В. Степанкова, «чільне місце посідала повага до короля та його влади» [13, с. 251-252]. Недаремно всі козацько-селянські повстання кінця XVI - початку XVII ст. були спрямовані проти магнатського панування, а не влади короля. Тому для Б. Хмельницького було важливим ще напередодні повстання повідомити український народ, що вістря своєї шаблі він спрямовує не проти короля, а проти підступних шляхтичів, які обманом відібрали в українців їхні права.

Довести законність його дій повинні були, на думку С. Величка, козацькі «привілеї», в яких король Ян II Казимир начебто підтверджував надане їм право «мушкетом i шаблею» боронити свої права, і які приховали ватажки реєстрового козацтва. Таким чином, на думку Б. Хмельницького, козаки мали право розпочати війну з поляками нібито «за королівським дозволом, адже поляки легковажили особу його королівської величності, не слухали його мандатів та наказів і насилали на Малу Росію безперервні руйнування та гніт» [2, с. 82]. Виходило, що, виступаючи проти магнатів, козаки не лише відстоювали свої права, а й захищали від них короля, якого ті почали зневажили й перестали слухати.

Отже, згадка про «привілеї від короля», надані Б. Хмельницькому, на першому етапі повстання, яке тільки набирало національно-визвольного характеру, повинна була виправдати його дії в очах населення, довести, що не лише за Божими, а й за державними законами Речі Посполитої, акції гетьмана та козацького війська носили справедливий та легітимний характер [2, с. 82]. На думку радянського й російського вченого Б. Флорі, Б. Хмельницькому вдалося переконати в цьому своїх прихильників. У всякому разі, на початковому етапі повстання козаки були впевнені не лише у законності свого виступу, а й в тому, що їхнім союзником є король [17, с. 42-43]. До того ж, і сам Б. Хмельницький, i його соратники, на думку українських дослідників В. Смолія та В. Степанкова, «спочатку не ставили за мету домагатися незалежності для України, а висунули у травні 1648 р. ідею створення автономної козацької держави у складі Речі Посполитої» [12, с.89]. Отже, теоретично король міг бути їх союзником.

Свою частку у створенні героїко-патріотичного інформаційного простору вносили й кобзарі, котрі в емоційно доступній формі прославляли подвиги повстанського війська, консолідуючи таким чином українське суспільство. Розуміючи значення кобзарів у 
ISSN 2518-1521 (Online), ISSN 2226-2830 (Print) ВІСНИК МАРІУПОЛЬСЬКОГО ДЕРЖАВНОГО УНІВЕРСИТЕТУ СЕРІЯ: ІСТОРІЯ. ПОЛІТОЛОГІЯ, 2019, ВИП. 26

боротьбі за українську державу, Б. Хмельницький поновив давньоруський звичай, коли під час походу кобзар мав їхати за першою особою у війську, тобто за гетьманом. Зберігся гетьманський універсал від 26 вересня 1652 р., яким Хмельницький наказував полковникам ставитися до кобзарів справедливо [11].

Задля підняття бойового духу війська й підтримки повстання широкими народними масами, Б. Хмельницький поширював інформацію про здобуті перемоги, про силу й велич повсталих. Це робилося для того, аби, як влучно підмітив український історик М. Костомаров, український народ «побачив і зрозумів, що його гнобителі не такі могутні й непереможні, як це здавалося; панська пиха впала під дружними ударами рабів, які зважилися, нарешті, скинути з себе ярмо неволі» [8, с. 224].

Як зазначалося вище, Б. Хмельницький спрямовував інформаційно-психологічні акції не лише на військо та український народ як своїх прихильників, а й на протилежний, ворожий табір. Проте форми подання інформації, через які козацькі ватажки намагалися вплинути на противника, багато в чому були аналогічними тим, які вони застосовували до своїх прихильників.

Так, у листах Б. Хмельницького до Владислава IV (12 червня 1648 р.), коронного маршалка А. Казановського (12 червня), князя В. Заславського (12 i 14 червня), брацлавського воєводи А.Кисіля (13 червня), як і у зверненнях до населення України, гетьман звертав увагу польського панства на зневагу, яку ті проявляли до козацтва, та докоряв їм у гнобленні руського народу та переслідуванні православного духовенства. Таким чином він намагався переконати польську еліту в тому, що повстання - це вимушений крок із їх боку [13, с. 254 ].

Використовуючи методи психологічного впливу, козаки намагалися схилити деякі військові підрозділи противника на свою сторону. Відомо, що напередодні першої битви під Жовтими Водами у травні 1648 р. до війська коронних гетьманів М. Потоцького та М. Калиновського, у складі якого перебували реєстрові полки, непомітно проникли запорозькі пластуни. Вони повинні були переконати козаків перейти на бік повстанців. Реєстровці, яких тоді очолював Ф. Джалалій, підтримали низовиків, що передрекло їх спільну перемогу.

Зі стародавніх часів методи психологічного впливу на супротивника застосовували для того, щоб посіяти страх і паніку в стані ворога, призвести до ескалації соціальних конфліктів у його середовищі, ввести в оману, спонукати воєначальників до прийняття помилкових рішень тощо.

Пам'ятаючи про розгубленість польського суспільства, що була викликана смертю короля Владислава IV у період найбільших успіхів козацького війська (літо 1648), Б. Хмельницький намагався розколоти польську еліту шляхом тимчасового усунення Яна II Казиміра. У 1651-1653 рр. козаки під керівництвом Л. Капусти планували операції із захоплення у полон польського короля [14, с. 94, 121, 129, 135].

У серпні 1648 р. козаки спробували вбити князя I. Вишневецького. До нього підіслали 10 юнаків 3 подарунками. Запідозривши зле, князь тримався 3 ними на відстані. Підпоївши козаків, вдалося дізнатися про справжні мотиви їхнього візиту, а під тортурами ті розповіли й про деталі операції [14, с. 118].

Тотожні до інформаційних операцій були диверсії, спрямовані на дестабілізацію ситуації на волості. Вони здійснювалися шляхом підбурювання суспільства до виступів проти існуючого польського режиму, організації в тилу ворога повстань селян і міщан. Подібні акції принесли очікуваний результат. Арештований у червні 1651 р. шляхтич 
ISSN 2518-1521 (Online), ISSN 2226-2830 (Print)

ВІСНИК МАРІУПОЛЬСЬКОГО ДЕРЖАВНОГО УНІВЕРСИТЕТУ

СЕРІЯ: ІСТОРІЯ. ПОЛІТОЛОГІЯ, 2019, ВИП. 26

В. Кулаковський, завербований одним із ватажків козацької розвідки Гржибовським, під тортурами свідчив, що він мав завдання з товаришами «бунтувати всіх селян, почавши від Кам'янця до Лянцкороні під Краковом», i «купи хлопців, збунтувавши, відправляти [їх] до Хмельницького» [16, с. 87].

У травні 1648 p. коронний гетьман М. Потоцький у листі до архієпископа М. Лубенського писав про те, що «козаки збунтували всю Україну» [14, с. 104]. А анонімний автор зазначав у 1648 р., що «руські міста йому [Хмельницькому - Авт.] самі добровільно й охоче піддаються; зібравшись 3 корогвами, бубнами виходять йому назустріч і їх йому під ноги кладуть» [15, с. 402].

В «Архіві Південно-Західної Русі» серед документів, що були зібрані комісією для розбору древніх актів, збереглося чимало свідоцтв того, як селяни, котрі були підбурені заїжджими козаками, грабували панські маєтки, розорювали фільварки, нападали на шляхтичів тощо [1, с. 281, 483, 484, 553].

Уже в липні 1648 р. в окремих українських воєводствах і повітах селяни та міщани почали організовуватися у військові загони, за типом козацьких [1, с. XL]. Як правило, такі ватаги діяли в межах одного-двох сіл, за рідким виключенням розповсюджуючись на більшу територію (як, наприклад, загін паволочського війта Івана Кучевича-Мінського) [1, c. XLI]. Проте їх діяльність дуже допомагала просуванню козацького повстанського війська. Налякані народним вибухом, «всюди міста й замки здаються без будь-якого спротиву, і кількість вогнепальної зброї зростає», - писав А. Кисіль у листі до брацлавського воєводи М. Лубенського 31 травня 1648 р. [3, с. 29].

Козацькі ватажки у походах проти татар і турків, а також під час антипольських повстань активно використовували метод, відомий з давніх часів як «уведення противника в оману». Але найбільшого розквіту мистецтво психологічного впливу на противника набуло саме в роки Національно-визвольної війни середини XVII ст. Саме війна дає нам чисельні приклади застосування цього методу. Сутність дезінформування полягала у наданні противнику свідомо викривленої інформації: неправдивих або не повних відомостей щодо намірів, чисельності, напрямів пересування козацьких загонів, поширення чуток тощо.

В. Степанков, аналізуючи джерела часів визвольної війни, дійшов висновку, що окремі козацькі розвідники «навмисне потрапляли до ворожих рук із метою дезінформувати польсько-литовське командування щодо чисельності українськокримського війська, його місця знаходження, планів командування» [14, с. 94]. Такі козаки вдавали з себе перебіжчиків з українського табору. Для того, щоб перевірити правдивість наданої ними інформації, поляки їх катували. Ці люди свідомо приймали мученицьку смерть під тортурами, аби дезінформувати ворога, повідомити йому неправдиву інформацію.

Так, напередодні Корсунської битви (травень 1648 р.) очільниками повстанського війська була проведена спеціальна операція з дезінформування. До рук поляків потрапило дев'ятеро татар і козак-перекладач. Під тортурами він «зізнався», що «козаків 7 тис. i підійшло ще 15, татар 47 тис. і наближається хан 3 ордою». М. Потоцький, збентежений тим, що в нього немає можливості успішно захищатися, залишив укріплений табір (Корсунь) і почав відступати до Богуслава. Вимаривши коронного гетьмана з укріпленої фортеці, у Гороховій Діброві (нині - Крута Балка на лівому березі р. Рось) його військо зустрів гарматним вогнем М. Кривоніс, а Б. Хмельницький разом із татарами вдарили в тил. Польське військо було знищено, а коронний гетьман потрапив у полон [16, с. 96]. 
ISSN 2518-1521 (Online), ISSN 2226-2830 (Print) ВІСНИК МАРІУПОЛЬСЬКОГО ДЕРЖАВНОГО УНІВЕРСИТЕТУ СЕРІЯ: ІСТОРІЯ. ПОЛІТОЛОГІЯ, 2019, ВИП. 26

Подібне дезінформування противника щодо кількості козацького війська відбувалося й перед іншими битвами з поляками: під Пилявцями, Зборовом та Берестечком.

Дезінформування противника мало на меті не лише підштовхнути очільників ворожого війська до ухвалення хибних рішень, а й поширити в його середовищі відчуття «постраху», соціальної напруги, настроїв приреченості, невпевненості у власних силах тобто, дезорганізувати його збройні сили. Б. Хмельницький з цього приводу зазначав: «Мені здається, що се більш чесно, ліпше і небезпечніше, коли поляки почують залізо у власній середині, коли матимуть щоденно перед очима ворогів» [6, с. 22].

В історію війни 1648 - 1657 pр. назавжди увійшла переможна битва козацькотатарських загонів проти коронного війська під Жовтими Водами. За словами козацького літописця, поляки тоді не встояли проти гетьмана й години i, «лігши на кілька тисяч трупів, з великим тріском і жахом ледве вскочили за свої окопи в обоз» [2, с. 67]. Велике значення для перемоги козацько-татарського війська відіграли страх і паніка, що поширилися серед польського війська. «Побачивши збиті кінськими копитами дим i куряву ..., полякам здавалося, - писав С. Величко, - що то йде стотисячне козацьке військо, але насправді йшло його тільки п'ятнадцять тисяч. Але полякам тоді страх затемнив очі млою - вони вже почали додуматися до такого, чого насправді й не було» [2, с. 69]. Це посіяло в стані ворога паніку. «Обидва гетьмани 3 багатьма іншими знаменитими панами неначе стратили розум, моталися навкруг обозу з багатьма хоругвами і не знали, що вдіяти» [2, с. 70]. На думку українського дослідника О. Уривалкіна, до дезінформування 3 метою «посіяти в рядах противника страх, невпевненість та паніку, козаки зверталися не раз» [16, с. 98].

Гетьман розробляв і складні комбінації з дезінформування. Зокрема, на другий день битви під Пилявцями (22 вересня 1648 р.) за його наказом до ворожого табору як полонений потрапив козак, переодягнений священиком. Під тортурами той повідомив про наближення для допомоги повстанському війську кількох десятків тисяч татар. Насправді їх підійшло в рази менше. Саме тоді Б. Хмельницький розпочав другу частину операції 3 дезінформування. Він наказав влаштувати союзницьким військам гучну зустріч із гарматним салютом. Виявлена козаками «радість» 3 приводу приходу татар, разом із попередньою інформацію про їх чисельність, породили серед поляків чутки про нашестя 30-тисячної орди. А це, своєю чергою, призвело до почуття приреченості й посіяло паніку.

На думку Т. Чухліба, заслання до противника «підставних» полонених із неправдивою інформацією стало «важливим складовим елементом «психологічної війни» Б. Хмельницького» [18].

Інколи для передавання хибної інформації козацькі ватажки використовували ворожих шпигунів (вивідувачів). Їм свідомо надавали неправдиві відомості, а потім організовували їх втечу. Траплялися випадки, коли обманна інформація до ворога потрапляла випадково, стихійно. Козаки, які потрапляли в полон, намагаючись врятувати своїх побратимів, направляли польське військо хибним шляхом.

Інформаційно-психологічні заходи загального характеру застосовувалися й до польського населення. На думку українського дослідника Ю. Мицика, розповсюдженою формою морально-психологічного тиску на військо й населення противника, яке часто використовували козаки, були листи образливого характеру [10].

Під час облоги м. Замостя восени 1648 р. до міста було направлено декілька листів, окремо - до полковника німецького гарнізону, міщан і шляхти. Цікаво простежити, як змінювалася риторики цих текстів. 
ISSN 2518-1521 (Online), ISSN 2226-2830 (Print)

ВІСНИК МАРІУПОЛЬСЬКОГО ДЕРЖАВНОГО УНІВЕРСИТЕТУ

СЕРІЯ: ІСТОРІЯ. ПОЛІТОЛОГІЯ, 2019, ВИП. 26

У перших листах козацькі ватажки (документи були підписані іменем Б. Хмельницького, проте дослідники вважають, що він лише підписував їх, a безпосередньо писали інші керівники війська) пояснювали мешканцям міста причини війни, закликали їх до переговорів, пропонували заплатити викуп тощо.

Коли ж ці умовляння не дали бажаного результату, на їх адресу почали надсилати застереження: «Ви сподіваєтесь на підкріплення, але не знаю, чи діждетесь його, бо чимало душ ваших воїнів пішло на дно Вісли, шукаючи цих ваших підкріплень». Після відхилення й цих закликів повстанців, зазвучали відверті погрози, що козаки зроблять 3 мешканцями те ж саме, що вчинили в м. Броди, де «не тільки місто з вогнем пішло, але й замок». I навіть погрози із глузуванням: «А ми божим іменем будемо про вас пильно дбати, коли ви не хочете живими лишитися, бо це не наша сила, а міць божа, справа божа, а бог завжди за кривди бідних гордих карає, так що, будьте ласкаві, робіть, як хочете» [7, с. 76-77].

Отже, риторика козацьких листів змінювалася від умовлянь до нещадних погроз. Використання таких інформаційно-психологічних прийомів мали на меті вплинути на поведінку людей, які сховалися за міськими мурами, та полегшити козакам отримати перемогу.

Загалом же, звернення до мешканців міст не чинити опір козацькому війську й таким чином запобігти розправи над ними, надсилалися й іншими очільниками повстанського війська. Так, Л. Капуста, який був одним із наближених осіб до гетьмана й запобіг декільком замахам на нього, у посланні до влади Перемишля наголошував: «Ті міста, які склонилися запорізькому війську, не було жодної найменшої кривди, крім тих, які супротивилися нам. Ми також християни, як і ви. Також обіцяємо вам чесним словом, що вам, панове міщани, не буде найменшої кривди, як і в інших містах, які не опиралися Запорізькому війську» [5, с. 73]

Подібні листи розсилалися й до польських селян. Зокрема, в універсалі, написаному в червні 1651 р. гетьман закликав селян підтримати його виступ. У разі перемоги він обіцяв звільнити їх від «повинностей і робіт» та надати такі вольності, які має шляхта [7, с. 629]. Під час війни серед польського війська розповсюджувалися й листи, в яких дискредитувалися польські ватажки.

Проте козацькі ватажки не відмовлялися й від так званих акцій залякування: розправи з польською шляхтою та їх прихильниками. Такі дії з боку повстанців мали на меті посіяти в польському, i, передусім шляхетському середовищі, відчуття приреченості та неминучості покарання. Особливою жорстокістю відзначився загін полковника І. Нечая, козаки якого, за участю міщан, чинили в Києві самосуд над поляками та євреями. Про те, що до цих акцій був безпосередньо причетний і Б. Хмельницький (в усякому разі, це відбувалося з його мовчазної згоди), на наш погляд, свідчить той факт, що, коли польські комісари нагадали йому про це, він не стримався і заявив: «Я маю право там (в Києві) розпоряджатися, як мені заманеться: я там пан і воєвода!».

Такі дії козаків досягли своєї мети: по всій Україні серед шляхти почалася паніка. «Раби тепер панують над нами, - писав брацлавський воєвода А. Кисіль архієпископу гнєзненському М. Лубенському. - Нещасні брати наші залишають свої гнізда, будинки й коштовні предмети. Всі тікають у внутрішні волості» [3, с. 28]. Проте й на волості не було спокою польським панам. Московський посланець у Варшаві Григорій Кунаков так описував настрої, що панували серед польської шляхти: «А многие сенаторы отпустили скарбы свои во Гданеск и хотят бежать за море... такова де злово несогласья и во всех 
ISSN 2518-1521 (Online), ISSN 2226-2830 (Print) ВІСНИК МАРІУПОЛЬСЬКОГО ДЕРЖАВНОГО УНІВЕРСИТЕТУ СЕРІЯ: ІСТОРІЯ. ПОЛІТОЛОГІЯ, 2019, ВИП. 26

людех ужасти николи в Польще и в Литве не бувало. А говорять всякие люди, что Бог у сенаторей ум отнял, а на шляхетство ужасть попустил, и слыша поляки про козаков, ужасаютца» [6, с. 27].

Підбурюючи українське населення підтримати повстанське військо й організовуючи диверсії в тилу противника, Б. Хмельницький i очолюваний ним уряд, на думку В. Степанкова, докладали чимало зусиль, намагаючись запобігти погромам міст і містечок, православних церков і монастирів, винищенню населення тощо [15, с. 412]. Закликаючи українців підтримати повстання, гетьман вимагав не чинити невиправдане насилля. Зокрема, Б. Хмельницький суворо заборонив М. Кривоносу «свавілля чинити, міста палити й руйнувати» $[7$, с. 63,67$]$. Оскільки той проігнорував його наказ, то був відкликаний зі своїми полками до табору, де їх покарали. Наказного гетьмана прикували ланцюгом до гармати, і відпустили лише після того, як він заплатив чималий штраф за свої дії. Щодо старшини - деяких із них ув'язнили, інших - стратили. [15, с. 413]. Таким чином розправлявся гетьман із побратимами, які відмовилися виконати його наказ. Але, на нашу думку, основна мета покарання полягала в тому, щоб ще раз довести українському народу, що козацьке військо $є$ його захисником, а не кривдником; а старшині й козакам - що вони повинні захищати, а не розправлятися з мешканцями волості.

Звичайно, що в тих умовах зупинити народну стихію, гнів щодо поневолювачів було надзвичайно складно. Але правдою $є$ й те, що гетьман застосував до війська весь арсенал психологічного впливу, яким він володів.

Вістря психологічних операцій козацького війська було спрямовано й проти союзників Речі Посполитої. Весною 1654 р. Б. Хмельницький направив монахів у Туреччину зі своїми «мандатами», щоб вони закликали «сербів, болгар, греків й інших християн до зброї проти турецького султана» [6, с. 88].

Визнаючи активне застосування козацьким військом різних форм інформаційнопсихологічного впливу на супротивника, постає питання щодо організаторів цих операцій. Вивчення наукової літератури дозволяє дійти висновків, що в козацькому середовищі не існувало органу, на який би покладалися функції розробки та проведення відповідних операцій. Часто організатором подібних заходів виступав сам Б. Хмельницький. Безпосередню участь у підготовці й проведенні таких акцій брали козацька старшина, полковники, сотники - командири козачих підрозділів.

Таким чином, психологічний тиск на противника та вплив на українське населення були складниками в організації збройної боротьби козаків та їх ватажків 3 метою створення української козацько-гетьманської держави. Під час Національно-визвольної війни з Річчю Посполитою у середині XVII ст. очільники козацького війська неодноразово використовували численні інформаційно-психологічні акції 3 метою переконання, дезінформування (надання перекручених, не повних або свідомо неправдивих відомостей) та дезорганізації (вчинення психологічних диверсій 3 метою посіяти у ворожому середовищі паніку, почуття страху, приреченості, соціальної напруги тощо) військ супротивника та польського населення.

Водночас, з метою підняття бойового духу козацько-селянського війська та надання широкої підтримки народних мас, інформаційно-психологічний влив здійснювався й на українське населення та воїнів повстанської армії. Емоційно забарвленні тексти, форми та засоби їх подання мали доволі сильний маніпулятивний інформаційний вплив на суспільство. 
ISSN 2518-1521 (Online), ISSN 2226-2830 (Print)

ВІСНИК МАРІУПОЛЬСЬКОГО ДЕРЖАВНОГО УНІВЕРСИТЕТУ

СЕРІЯ: ІСТОРІЯ. ПОЛІТОЛОГІЯ, 2019, ВИП. 26

\section{Список використаної літератури}

1. Архив Юго-Западной России, издаваемый комиссией для разбора древних актов, состоящей при Киевском, Подольском и Волынском генерал-губернаторе. - Киев : Университет Св. Владимира. - Ч. 3, T. IV : Акты, относящиеся к эпохе Богдана Хмельницкого. - 946 с. ; Arkhiv Yugo-Zapadnoy Rossii, izdavaemyy komissiey dlya razbora drevnikh aktov, sostoyashchey pri Kievskom, Podolskom i Volynskom general-gubernatore. Kiev : Universitet Sv. Vladimira. - Ch. 3, T. IV : Akty, otnosyashchiesya k epokhe Bogdana Khmelnitskogo. - $946 \mathrm{~s}$.

2. Величко С. В. Літопис / С. В. Величко; відп. ред. О. Мишанич; перекл. з книж. укр. мови В. О. Шевчук. - Київ : Дніпро, 1991. - Т. I. - 369 с. ; Velychko S. V. Litopys / S.V. Velychko; vidp. red. O. Myshanych; perekl. z knyzh. ukr. movy V. O. Shevchuk. - Kyiv : Dnipro, 1991. - T. I. - 369 s.

3. Воссоединение Украины с Россией : документы и материалы в 3-х т. / ред. кол. П.П. Гудзенко, А. К. Касименко, А. А. Новосельский. - Москва : Издательство Академии наук СССР, 1953. - Т. II : 1648 - 1651 годы. - 567 с. ; Vossoedinenie Ukrainy s Rossiey : dokumenty i materialy v 3-kh t. / red. kol. P. P. Gudzenko, A. K. Kasimenko, A. A. Novoselskiy. - Moskva : Izdatelstvo Akademii nauk SSSR, 1953. - T. II : 1648 - 1651 gody. - 567 s.

4. Горобець В. Таємниці, казуси і курйози української історії. Козацька доба / В.Горобець, Т. Чухліб. - Київ : Наукова думка, 2004. - 310 с. ; Horobets V. Taiemnytsi, kazusy i kuriozy ukrainskoi istorii. Kozatska doba / V. Horobets, T. Chukhlib. - Kyiv : Naukova dumka, 2004. - $310 \mathrm{~s}$.

5. Грабовецький В. Західноукраїнські землі в період народно-визвольної війни 16481654 pp. / В. Грабовецький. - Київ : Наукова думка, 1972. - 192 с. ; Hrabovetskyi V. Zakhidnoukrainski zemli v period narodno-vyzvolnoi viiny 1648-1654 rr. / V. Hrabovetskyi. Kyiv : Naukova dumka, 1972. - 192 s.

6. Джеджула Ю. Таємна дипломатія Богдана Хмельницького : історикодокументальна оповідь / Ю. Джеджула . - Київ : Молодь, 1995. - 224 с. ; Dzhedzhula Yu. Taiemna dyplomatiia Bohdana Khmelnytskoho : istoryko-dokumentalna opovid / Yu. Dzhedzhula. - Kyiv : Molod, 1995. - 224 s.

7. Документи Богдана Хмельницького. 1648 - 1657 / відп. ред. Ф. П. Шевченко, упоряд. І. П. Крип'якевич. - Київ : Вид-во Академії наук Української РСР, 1961. - 740 с. ; Dokumenty Bohdana Khmelnytskoho. 1648 - 1657 / vidp. red. F. P. Shevchenko, uporiad. I.P. Krypiakevych. - Kyiv : Vyd-vo Akademii nauk Ukrainskoi RSR, 1961. - 740 s.

8. Костомаров Н. П. А. Кулиш и его последняя деятельность / Н. Костомаров // Киевская старина. - 1883. - Т. 5, № 2. - С. 221-234 ; Kostomarov N. P. A. Kulish i ego poslednyaya deyatelnost / N. Kostomarov // Kievskaya starina. - 1883. - T. 5, № 2. - S. 221-234

9. Куцька О. М. Психологічна боротьба в історії українського козацтва / О.М. Куцька // Вісник Національного університету «Львівська політехніка». - 2003. - № 474 : Держава та армія. - C. 3-12 ; Kutska O. M. Psykholohichna borotba v istorii ukrainskoho kozatstva / O.M. Kutska // Visnyk Natsionalnoho universytetu «Lvivska politekhnika». - 2003. - № 474 : Derzhava ta armiia. - S. 3-12.

10. Мицик Ю. Розвідники Богдана Хмельницького / Ю. Мицик // Армія України. 1995. - 19 грудня ; Mytsyk Yu. Rozvidnyky Bohdana Khmelnytskoho / Yu. Mytsyk // Armiia Ukrainy. - 1995. - 19 hrudnia.

11. Під час походу кобзар мав їхати за гетьманом [Електронний ресурс] // Хрещатик. - 2001. - 12 жовтня № 137. - Режим доступу : http://kreschatic.kiev.ua/ua/1967/art/1133.html ; 
ISSN 2518-1521 (Online), ISSN 2226-2830 (Print) ВІСНИК МАРІУПОЛЬСЬКОГО ДЕРЖАВНОГО УНІВЕРСИТЕТУ

СЕРІЯ: ІСТОРІЯ. ПОЛІТОЛОГІЯ, 2019, ВИП. 26

Pid chas pokhodu kobzar mav yikhaty za hetmanom [Elektronnyi resurs] // Khreshchatyk. 2001. - 12 zhovtnia № 137. - Rezhym dostupu : http://kreschatic.kiev.ua/ua/1967/art/1133.html

12. Розвідка й контррозвідка та їх роль у боротьбі за незалежність України наприкінці XVI - в середині XVII ст. // Смолій В. Спеціальні служби України від найдавніших часів і до сьогодення : у 5-ти т. / В. А. Смолій, М. Ф. Котляр, В. С. Степанков. - Київ, 2017. - Т. 1 : Спецслужби України у IX - середині XVII ст. - С. 66-220 ; Rozvidka у kontrrozvidka ta yikh rol u borotbi za nezalezhnist Ukrainy naprykintsi XVI - v seredyni XVII st. // Smolii V. Spetsialni sluzhby Ukrainy vid naidavnishykh chasiv i do sohodennia : u 5-ty t. / V. A. Smolii, M. F. Kotliar, V. S. Stepankov. - Kyiv, 2017. - T. 1 : Spetssluzhby Ukrainy u IX seredyni XVII st. - S. 66-220.

13. Степанков В. Зрада королю чи законне право на виступ? (Козацьке повстання першої половини 1648 року у сприйнятті Війська Запорозького / В. Степанков// Соціум. 2006. - № 6. - C. 249-256 ; Stepankov V. Zrada koroliu chy zakonne pravo na vystup? (Kozatske povstannia pershoi polovyny 1648 roku u spryiniatti Viiska Zaporozkoho / V. Stepankov// Sotsium. - 2006. - № 6. - S. 249-256.

14. Степанков В. Розвідка і контррозвідка Богдана Великого (1648- 1657 рр.) / В.С. Степанков. - 3-е вид., перероб. та розшир. - Кам'янець-Подільський, 2008. - 264 с. ; Stepankov V. Rozvidka i kontrrozvidka Bohdana Velykoho (1648- 1657 rr.) / V. S. Stepankov. 3-e vyd., pererob. ta rozshyr. - Kamianets-Podilskyi, 2008. - 264 s.

15. Степанков В. 1648 рік: початок Української революції чи «домової війни» в Речі Посплитій? / В. Степанков // Україна в Центрально-Східній Європі. - 2003. - Вип. 3. C. 371-416 ; Stepankov V. 1648 rik: pochatok Ukrainskoi revoliutsii chy «domovoi viiny» v Rechi Posplytii? / V. Stepankov // Ukraina v Tsentralno-Skhidnii Yevropi. - 2003. - Vyp. 3. S. 371-416.

16. Уривалкін О. М. Таємниці розвідок (діяльність таємних служб на території України) / О. М. Уривалкін. - Київ : КНТ, 2007. - 352 с. ; Uryvalkin O. M. Taiemnytsi rozvidok (diialnist taiemnykh sluzhb na terytorii Ukrainy) / O. M. Uryvalkin. - Kyiv : KNT, 2007. $-352 \mathrm{~s}$.

17. Флоря Б.Н. Отношение украинского козачества к Речи Посполитой во время козацьких восстаний 20-30-х годов XVII века и на начальном этапе народноосвободительной войны / Б. Н. Флоря // Славяноведение. - 2002. - № 2. - С. 36-51 ; Florya B.N. Otnoshenie ukrainskogo kozachestva k Rechi Pospolitoy vo vremya kozatskikh vosstaniy 20-30-kh godov XVII veka i na nachalnom etape narodno-osvoboditelnoy voyny / B. N. Florya // Slavyanovedenie. - 2002. - № 2. - S. 36-51.

18. Чухліб Т. Психологічна війна гетьмана Б.Хмельницького / Т. Чухліб // Народна армія. - 2002. - 24 грудня ; Chukhlib T. Psykholohichna viina hetmana B.Khmelnytskoho / T. Chukhlib // Narodna armiia. - 2002. - 24 hrudnia

Стаття надійшла до редакції 09.10.2019 p.

\section{S. Liaskovska}

\section{A. Liaskovska \\ INFORMATION AND PSYCHOLOGICAL IMPACT EXERTED BY COSSACK LEADERS DURING THE NATIONAL LIBERATION WAR OF THE UKRAINIAN PEOPLE IN THE MID 17th CENTURY}

On the bases of the facts known in Ukrainian historiography and previously published documentary materials, the article suggests that information and psychological operations 
ISSN 2518-1521 (Online), ISSN 2226-2830 (Print)

ВІСНИК МАРІУПОЛЬСЬКОГО ДЕРЖАВНОГО УНІВЕРСИТЕТУ

СЕРІЯ: ІСТОРІЯ. ПОЛІТОЛОГІЯ, 2019, ВИП. 26

constituted a part of the armed struggle of Cossacks and their leaders for the creation of the Ukrainian Cossack-Hetman state during the National Liberation War of 1648-1657. The purpose of such operations was to create an information space favorable for the rebels, to unite the masses of the Cossacks around the Cossack troops and to raise the morale of the troops; to demoralize and disorganize the enemy troops, to neutralize or even win individuals and groups over from the enemy camp. In accordance with the goals set, certain objects that fell under the influence of information and psychological actions performed by Cossack army leaders and, in particular, B. Khmelnitsky, were defined. They were Cossacks and all those who joined the Ukrainian rebellious army, the Ukrainian population (peasants, lower middle class, Orthodox clergy, nobility); registered Cossacks, who were on the Polish king's service, Polish crown army soldiers (infantrymen) and mass mobilization soldiers (noble host); the Polish population living in the Ukrainian lands - the theater of war, the king and military leaders of the Polish army and their allies. The article analyses technologies (content, forms and means of information presentation) used by Cossack leaders for information and psychological impact on great masses of Ukrainian and Polish population, taking into account their national, social, intellectual and ethno-linguistic characteristics. The paper also considers the language means used for emotional coloring of Universals (legal acts) and other documents. The peculiarities of applying methods of psychological pressure on the enemy and his allies are looked at in the paper. These methods comprise conviction, disinformation (provision of distorted, incomplete or deliberately false information), psychological subversion (acts of intimidation) in order to destabilize the situation in the rear (provoking social outbursts against the Polish regime, staging of uprisings) and disorganization of the enemy's army (stirring up perplexity, creating panic, fuelling fear, evoking the feeling of doom, inevitability of reprisals, etc.). Attention is also drawn to B. Khmelnytsky's attempts to prevent excessive cruelty and violence. The forms and channels as well as lexical means through which the impact was exerted are defined.

Key words: B. Khmelnytsky, Cossacks, National Liberation War, information and psychological impact, misrepresentation of information, disorganization, psychological subversion.

\section{УДК 929Тетчер:364(410)"193/200"}

\section{А. В. Папазова \\ К. Д. Андрющенко}

\section{ПОГЛЯДИ МАРГАРЕТ ТЕТЧЕР НА ПЕНСІЙНЕ ЗАБЕЗПЕЧЕННЯ ГРОМАДЯН}

Розглянуто формування та розвиток поглядів Маргарет Тетчер під впливом консервативних ідей, участі в діяльності відділень консервативної партії та положень доповіді економіста У. Беверіджа у період перебування ї̈ на посаді парламентського секретаря в Міністерстві у справах пенсій та державного страхування. Простежено зміну поглядів М. Тетчер на пенсійну систему Великобританії: від державної пенсійної системи до системи з часткою приватного пенсійного забезпечення. Зроблено висновок, щзо Тетчер цікавили не лише фінансові проблеми держав за економічної кризи, а й питання справедливості щзодо пенсіонерів і робітників, які працюють. 